\title{
Die toekoms van die klein plattelandse gemeente
}

\begin{abstract}
Author:
H. Jurgens Hendriks ${ }^{1}$

Affilation:

${ }^{1}$ Department Practical

Theology and Missiology,

Stellenbosch University,

South Africa

Note:

This article was initially presented as a paper at the annual meeting of the Practical Theology Society of South Africa on June 21 2012. It was one of six papers presented as: 'The critical interaction between small rural communities - six case studies within the South African context.'

This article is published in the section Practical Theology of the Society for Practical Theology in South Africa.

\section{Correspondence to:}

Jurgens Hendriks

Email:

hjh@sun.ac.za

Postal address:

171 Dorp Street,

Stellenbosch 7600,

South Africa

Dates:

Received: 23 June 2012

Accepted: 24 Aug. 2012

Published: 19 Oct. 2012

How to cite this article: Hendriks, H.J., 2012, 'Die toekoms van die klein plattelandse gemeente', HTS Teologiese Studies/ Theological Studies 68(2), Art. \#1287, 8 pages. http:// dx.doi.org/10.4102/hts. v68i2.1287
\end{abstract}

(C) 2012. The Authors. Licensee: AOSIS OpenJournals. This work is licensed under the Creative Commons Attribution License.
The future of the small rural congregation. The article addressed the plight of small rural congregations by relating the results of three visits to ten congregations in the Western Cape and Karoo region of South Africa. The research goal was to help these congregations theologically become missional and kingdom focussed. As such it implied a transformation process, moving from a nationalistic-denominational and maintenance-institutional stance to that of getting the whole community's involvement to address the burning local issues that affect all. The issues that surfaced and the process that was followed are described.

\section{Inleiding}

Die problematiek van die klein plattelandse gemeente is vir 'n geruime tyd op die radarskerm van die Nederduitse Gereformeerde Kerk (NGK). Opdragte van sinodes, werk van kommissies en navorsing is in al die sinodes gedoen (Kleingemeentes 2012). ${ }^{1}$ Die verskynsel is globaal en hang saam met internasionale veranderingsprosesse. ${ }^{2}$

Die ontvolking van die platteland het tot gevolg dat die gemeentes finansieel nie meer 'n leraar kan bekostig nie. Finansies is dus oënskynlik die probleem. Enigeen vertroud met die gemeentes sal egter weet dat ' $n$ meer genuanseerde verstaan van die probleem nodig is. Die doel van die navorsing is om die gemeentes en gemeenskappe te help.

Hierdie spesifieke ondersoek en die spanverband waarin dit gedoen word, vra tans 'n meer genuanseerde vraag, naamlik: Hoe sien die klein plattelandse gemeente sigself? As die gemeente sigself sien as 'n gemeente van 'n bepaalde denominasie of rassegroep, is dit die begin van die einde. As die gemeente sigself egter as ' $n$ missionale gemeente sien wat op die hele gemeenskap gefokus is en wat geloofonderskeidend voor die Drie-eenheid staan en van God sy roeping en opdragte kry, is dit die begin van ' $n$ nuwe verhaal. Die hipotese is dus eenvoudig: as die klein plattelandse gemeente missionaal op die totale gemeenskap gefokus is, gaan nuwe moontlikhede oop en is haar bestaansdoel die koninkryk van God, nie die lotgevalle van een seksie mense van die gemeenskap nie. Die uitdaging is om gemeentes op hierdie pad te begelei.

Hierdie artikel is 'n verslag oor 'n gefokusde empiriese studie wat in opdrag van die NGK se Wes-Kaapse Sinode en Communitas, in samewerking met die NGK van Noord-Kaap onderneem is in 10 gemeentes in 'n bepaalde geografiese area. ${ }^{3}$ Die betrokke gemeentes was almal reeds besoek in 2009. Die leraar van Carnavon het die inisiatief geneem en die Plattelandse Gemeente Ondersteuningsaksie geloots en deur Communitas die navorser se besoeke as opvolgbesoeke gereël. Dit het uitgeloop op drie besoeke in 2011. Die eerste twee was gemeentebesoeke waar die navorser en sy vrou eers agt gemeentes in April en tien in September 2011 besoek het. Dit is in Oktober opgevolg deur 'n gesamentlike konferensie in Calvinia.

Die opdrag aan die navorser was ' $n$ pastorale besoek aan die gemeentes, en om na soveel as moontlik mense of identifiseerbare groepe te luister. Ons is versoek om die leraar en sy vrou te ondersteun asook om die interaksie tussen die gemeente en leraarspaar te versterk. Die betrokke gemeentes was in ' $\mathrm{n}$ minder en meerdere mate getraumatiseer, finansieel en in terme van onderlinge verhoudinge.

\section{Metodologie}

Die gemeentes het vooraf kennis van die besoek gekry en is gevra om self te reël dat soveel as moontlik groepe en mense met die luisterspan gesprekke voer. Daar was geen vaste agenda

1.Daar is baie literatuur oor klein gemeentes waarvan ' $n$ lys verskyn in die verslag oor klein gemeentes wat in Oktober 2011 voor die Algemene Sinode gedien het (kyk http://kleingemeentes.co.za/wp-content/uploads/as2011verslag/verslag-kleingemeentes-as2011.pdf).

2.Lees byvoorbeeld Jung en Agria (1997); Dudley en Ammerman (2002).

3.Die gemeentes is, van wes na oos: Nieuwoudtville, Loeriesfontein, Calvinia Moeder en Calvinia Hantam, Brandvlei, Sutherland, Williston, Carnavon, Vosburg en Loxton. 
nie. Ons het doodeenvoudig in die styl van informele dataversameling in die vorm van semi-gestruktureerde onderhoude en fokusgroeponderhoude na die verskillende groepe geluister. Hulle is gevra om ons te vertel van die lief en leed, die probleme en uitdagings van die gemeente (De Vos et al. [1998] 2011:341-375). Temas was gou duidelik en dié temas is in die vorm van semi-gestruktureerde vrae in opeenvolgende gemeentes herhaal. Elke gemeente het na elke besoek 'n verslag oor die besoek aan die gemeente ontvang asook die algemene en oorsigtelike verslag waarin tendense en bevindinge uitgelig is.

Die doel was om te luister. Die gemeentes wou almal verstaan wat die makro faktore is wat hulle omgewing beïnvloed en verander. Die navorser het dit dan verduidelik (temas word later vermeld). Teologies was die vraag dan wat God se roeping in hulle omstandighede behels. Geen voorstelle is voorskriftelik gemaak nie want dit sou hulle van die eienaarskap van wat gedoen moet word, vervreem. Die hulp wat aangebied is, was fasiliteringshulp wat nie onderskraging, bystand en blywende betrokkenheid sou uitsluit nie. Die teologiese vertrekpunt was: dit is God se kerk en gemeentes. Die proses van hulp en ondersteuning moet 'n geloofonderskeidingsproses wees waarin die gemeente self die sleutelrol speel. Selfs die wetenskaplike navorsingsprosesse waar van interdissiplinêre navorsingstegnieke gebruik gemaak is, bly hieraan onderhewig. Dit is deel van 'n geloofsgebaseerde soeke na die wil van God. In navorsingstaal is die studie deskriptief-etnografies van aard. Die verslagtrant beskryf die heersende kultuur in die fenomeen wat ondersoek word (Babbie \& Mouton 2010:80-81). Gevolgtrekkings word op grond van die beskrywing gemaak.

Na die eerste besoek het elke gemeente ' $n$ persoonlike verslag van die gesprekke en besoek in die gemeente ontvang. Deel (b) van die verslag was 'n samevatting van die tendense wat in al die gemeentes duidelik geword het. Die verslae is met groot waardering ontvang en het die opvolgbesoek meer doelgerig gemaak met meer gefokusde vrae en bespreking. Die algemene verslag van die Aprilbesoek is aangebied by die Algemene Sinode se beraad oor Klein Plattelandse Gemeentes in Mei 2011 te Kemptonpark. Dit het 'n bepalende invloed gehad op die verslag wat vir die Algemene Sinode opgestel is. Die Algemene Sinode verslag is voor die Septemberbesoeke aan al die gemeentes gestuur. Al die gemeentes kon dus sien dat daar baie deeglik van hulle bydraes kennis geneem is en dat die kerk in sy sinodale verband erns maak met die sake op die agenda. Die samewerking en gesindheid was dus uiters positief in September- en by die Oktoberkonferensie.

Vyf van die tien gemeentes het brug- of aflospredikante gehad. Een gemeente het pas 'n nuwe predikantspaar ontvang en vier se predikante was onderskeidelik 2, 5, 7, en 23 jaar in hul onderskeie gemeentes. Laasgenoemde leraar het einde 2011 ' $n$ beroep aanvaar. Slegs drie van die vyf permanente leraars ontvang op skaal vergoeding. Die volgende rubrieke van die artikel is ' $n$ samevatting van die twee algemene verslae wat aan die tien gemeentes gestuur is. Dit sal gevolg word deur 'n kort oorsig van wat by die gesamentlike konferensie gebeur het en die artikel se finale gevolgtrekkings.

\section{Die aanknopingspunt by die gesprekke}

Die navorsing is missionaal gemotiveerd ${ }^{4}$ met ' $n$ bepaalde hermeneutiese en teologiese invalshoek. Die kerk is God se instrument om sy koninkryk te laat kom. Die inleiding by al die gesprekke was Psalm 127:1:

As die Here die huis nie bou nie, swoeg dié wat daaraan bou, tevergeefs.

As die Here die stad nie beskerm nie, waak dié wat dit beskerm, tevergeefs.

Die Aprilverslag ${ }^{5}$ lees dan (effens geredigeer).

Die Bybel is vol voorbeelde van tye in die geskiedenis van Israel waarin God en godsdiens gebruik is as 'n soort laaste bastion. Die veronderstelling is dat jy God se guns kan verdien met goeie werke of vroom gewoontegodsdiens ('n instandhoudingsbediening). Dit is tragies as die dissipels self na Jesus se opstanding uit die dood, by sy hemelvaart, vra wanneer Hy die Koninkryk van Israel gaan oprig (Hand 1:6). In hulle koppe was 'n onuitgesproke wens van ' $n$ eie nasionale staat, 'n situasie waar hulle van 'die ander', in hulle geval die Romeine, verlos sou word. Hulle wou praat van 'ons kerk' en sien Jesus as iemand tussen Superman en 'n versekeringspolis teen die ergste ongelukke. Dat hierdie geloof ' $n$ groot versoeking vir gelowiges in klein plattelandse gemeentes is, staan nie te betwyfel nie. Dit is egter hierdie geloof wat die finale doodskisspyker vir enige mens en gemeente is. Mens sien dit tragies geilllustreer in ultrakonserwatiewe kerke. Dit is 'n godsdiens sonder vreugde, 'n sektariese onttrekking van 'n roeping oneindig groter en wonderliker. Die opstanding uit die dood van hierdie godsdiens vra altyd ' $n$ sterwe aan die self.

Die aanhaling vertolk duidelik die navorser(s) se geloof en die navorsing se hipotese dat klein plattelandse gemeentes dikwels misbruik word vir nasionalisties-politiese redes. Dit is eers wanneer hierdie gemeentes vry word en God self deur die Heilige Gees vir hulle in hulle gemeenskap begin gebruik, dat alles sal verander.

\section{Lidmaatskaptendense}

Hierdie afdeling en die volgendes is geredigeer uit die April- en September 2012 verslae aan die tien gemeentes. Die navorser ag dit noodsaaklik om dit so weer te gee aangesien dit die tipe kommunikasie wat met die gemeentes gevoer is, illustreer.

Agt van die tien NGK gemeentes is voor 1900 afgestig! Die ontvolking van die platteland en die daling in dooplidmate (dalende geboortekoers) is opvallend. As mens 1994, die jaar waarin die nuwe bedeling 17 jaar gelede ingelui is, as jou

4.Kyk Guder (1998); Hendriks (2004) en Niemandt (2007). Vir ‘n baie goeie oorsig kyk Sheridan(2012)

5.Kyk Hendriks (2011a:26-27). 
anker jaar neem en jy gaan 17 jaar terug na 1977 (NGK 1977) en kyk na die getalle, is die tendens duidelik. Die huidige 3229 totale lidmatetal van die tien gemeentes is maar $60 \%$ van wat dit in 1995 (NGK 1995) was (5402) en 39\% van wat dit in 1977 was (8257) (NGK 1977). Een rede vir die dalende getalle is die dalende geboortesyfer. In 1977 was dooplidmate 31\% van die totale lidmaattal, 25\% in 1994 en 17\% in 2011 (NGK 2011). Boerderyeenhede word ook groter, die meeste boere het óf grond bygekoop óf huur grond by. Baie plaaseienaars woon elders, telkens nie eers op die naaste dorp nie. Leë plaashuise is oral te sien. Plae soos jakkalse, rooikatte en sprinkane neem toe.

Die gevolg hiervan op die al tien die dorpe is dramaties. Die koshuise en skole op meeste van die dorpe, met die uitsondering van Calvinia, is feitlik volledig deur kleurlinge oorgeneem. Verwaarlosing het oral opsigtelik ingetree. NGKlidmate se kinders gaan grotendeels na goeie skole buite die gebied en skoolkar ry het deel van die kultuur geword. Daar word van tuisonderrig en privaatskole deur die meer gegoede mense van die gemeenskappe gebruik gemaak (hier is nie 'n kleurverdeling nie).

Daar is ooglopende agteruitgang in al die dorpe duidelik. Besighede en professionele dienste verminder. Die meeste dorpe word swakker bestuur en agteruitgang van dienste is duidelik. Vosburg en Loxton doen baie om hulle dorpies netjies te hou. Dit het ' $n$ positiewe uitwerking op toerisme.

\section{Finansies}

Finansies is by al tien gemeentes 'n saak van kommer. Plattelandse lidmate gee 'n hoër gemiddelde dankoffer as lidmate in voorstedelike gemeentes. Elke gemeente is uniek en probleme om die boeke te laat klop is een of ander tyd elkeen se voorland. Daar is egter merkwaardige inisiatief en oorspronklikheid in die wyse waarop die gemeentes fondse insamel en by meer as net hulle eie voortbestaan betrokke is. Die volgende faktore speel 'n rol:

1. Diekonteks: Dielandbouhet tanshoërinsetkostes as vroeër. Die regering is onsimpatiek teenoor die landboubedryf. Die agteruitgang van paaie en dergelike infrastruktuur asook die koste van kinders se opvoeding, vra veel groter finansiële insette. Dit word algemeen aanvaar dat jy nie in hierdie streek binne ' $n$ leeftyd die kapitale waarde van 'n plaas, implemente en vee kan uitboer nie. Ten einde die boeke te laat klop raak die aantal bewoonde plase minder en die boerderyeenhede raak groter. Die daling in lidmaatgetalle en die aantal plaaswyke in elkeen van die gemeentes, toon dit duidelik aan.

2. Droogte: Die meeste gemeenskappe het oor jare 'n spaarfilosofie met die oog op moeilike tye ontwikkel. Geld op belegging is egter geestelik gevaarlik as die uitsluitlike doel selfhandhawing is. Sonder dat hierdie tipe belegging as sodanig veroordeel word, bly dit 'n vraag of kerke met groot beleggings kan sit as daar in hulle midde diepe hartseer en nood is en as hulle hul leraar onderbetaal.

3. Groot uitgawes aan die kerk of pastorie: Die verantwoordelike ding om te doen is om ' $n$ instandhoudingsfonds te hê wat oploop om - as dit die dag nodig is - groot uitgawes te dek. Van die mooiste en oudste kerkgeboue met 'n trotse geskiedenis staan in hierdie plattelandse gemeentes. Op ' $n$ gemiddelde Sondag is daar baie selde meer as $10 \%$ van die sitplekke in die kerk gevul. Gemiddeld is die totale lidmaattal van die gemeentes minder as $40 \%$ van die sitplekke van die kerkgebou waar hulle aanbid. 'n Jong diaken op Brandvlei sê vir my: 'Dominee, ek voel die hele tyd skuldig. Ek voel skuldig dat ons kerk so leeg is en agteruitgaan en ek voel skuldig dat ek my geld gee vir die instandhouding van geboue as daar soveel ander nood om ons is. Ons het veel sinvoller kerk in ' $\mathrm{n}$ groot sitkamer.'

4. 'n Predikant op topskaal raak moeilik bekostigbaar: As alles goed gaan kan dit soms haalbaar wees, maar gewoonlik is die topskaal-dominee meer as 20 jaar in die gemeente en is daar soveel opgehoopte frustrasie, dat dankoffers daal. Hieraan sal die kerkverband ernstig aandag moet gee. Daar is ander opsies.

5. Die mees destruktiewe faktor vir enige gemeente se finansies is onenigheid en verdeeldheid in die gemeente en gemeenskap. Die voortbestaan van die klein plattelandse gemeente en gemeenskap hou verband met die aanwesigheid al dan nie van leierskap wat die totale gemeenskap kan help om hulle probleme en uitdagings aan te spreek. Verdeeldheid onder byvoorbeeld die blanke gedeelte van ' $n$ gemeenskap is dus katastrofies. Maar selfs as dié sektor van die gemeenskap goed saamwerk, is die totale gemeenskap lotsgebonde en is almal se samewerking nodig.

Vanuit 'n teologiese hoek is finansies 'n sekondêre faktor. Die Koninkryk van God gaan nie in die eerste plek om besittings nie. Dit is altyd 'n slegte teken as 'n kerkraad se agenda deur die finansiële komitee se sake oorheers word. Natuurlik sê die Nuwe Testament baie duidelik dat ons goeie ekonome moet wees. Ekonomie in sy Bybelse betekenis verwys na die goeie bestuur van die huishouding van God, dié soort bestuur wat lei tot ' $n$ bedeling waarin daar geregtigheid, vrede en liefde is en mense met God en skepping versoen is.

Die klein plattelandse gemeente voel dikwels skuldig dat feitlik al hulle geld in die betaal van ' $\mathrm{n}$ dominee se salaris, medies en pensioen ingaan - so asof dit selfsugtig net om geestelike selfversorging gaan. In sommige gevalle kan dit so wees. Indien 'n gemeente egter missionaal Koninkryksgerig lewe en 'n verskil in sy omgewing maak, hou die siening nie water nie. Deur iemand voltyds af te sonder vir die werk wat ' $\mathrm{n}$ leraar in die gemeente en gemeenskap doen, lewer die gemeente ' $n$ groot bydrae aan die hele omgewing en is dit tot voordeel van almal wat daar woon, ongeag hulle kerkverband. Ek het dit besef deur waar te neem wat meeste van die leraars doen en beteken. Mens kan sê dat hulle die gemeente se sout-wees in die omgewing koördineer en moontlik maak.

\section{Verhoudings en diversiteit}

Hier lê die sleutel tot die verstaan, probleme en uitdagings van die bediening in die plattelandse gemeente. Ek het 
gevind dat waar ek versoek is om 'n teoretiese inset te maak om die samelewingsveranderinge te verduidelik (sien hierna wat dit behels het), dit tot ' $n$ veel beter insig en bespreking aanleiding gegee het.

Stedelike gemeentes het die luukse dat gelowiges na 'n gemeente kan gaan waar hulle inpas in terme van sake soos spiritualiteit, teologie of wat ook al. Die karakter van 'n plattelandse gemeente word gewoonlik vergelyk met die beeld van 'n uitgebreide familie. Die kerk en gemeenskap het al sy lede nodig om te oorleef want samewerking is essensieel vir die voortbestaan van die kleiner gemeente, finansieel sowel as in baie ander opsigte ook. Die mense is op mekaar aangewese van skoolkar ry, sprinkane spuit, vure veg tot die hantering van elke vorm van krisis.

\section{Die rol van die leraar}

Tipies van alle klein plattelandse gemeentes die wêreld oor, speel die leraar die sleutelrol as gemeenskapsleier, as ' $n$ ietwat onafhanklike inkommer, as die een wat die diversiteit in die gemeente en gemeenskap moet bestuur. 'n Verhoudingssensitiewe leraar wat die gemeente deur sy swaarkrytye kan help om in geloofsvertroue op God te bly fokus en in voorspoedtye die gemeente kan help om nie die Here te vergeet nie (Deut 8) en wat as apostolêre leier profetiese, koninklike en priesterlike funksies vervul, is onontbeerlik. Geen salaris kan hiervoor vergoed nie want dit gaan om veel meer as net ' $n$ salaris. Dit gaan om die gemeente te help om missionaal op God se agenda gefokus te bly en nie te verval in ' $n$ instandhoudingsbediening nie. Laasgenoemde is die stadige-sterf opsie wat begin met skeurings en die verloor van die jonger geslag. Sonder God se genade oor ' $n$ leraar kan niemand dit in eie krag vermag nie.

Vir die plattelandse leraar is huisbesoek by sy lidmate ononderhandelbaar. Jy moet by die vendusie wees en die koöperasie ken, die polisie besoek en die ouetehuis nie vergeet nie! Ek het opgemerk hoe gemeenskappe dit waardeer as die leraar uitreik en oor grense beweeg. Hy moet al die kerke en die dominees wat een keer in 'n aantal maande 'n paar lidmate kom besoek, ken. Hy is die brugbouer, die een wat versoening bewerkstellig en gesamentlike projekte help loots. Hy moet die voorbeeld stel van wat dit beteken om 'n Koninkryksvisie te hê.

\section{Die verlies van verhoudingsvaardighede}

Dit is opvallend dat dit die koshuiskinders uit die platteland is, wat op universiteit en in die werkplek die beste aanpas. Die platteland se groot familiekonteks leer kinders en mense verhoudingsvaardighede. Nogtans is hierdie vaardighede vandag onder druk. Die woord 'individualisme' is tiperend van die DNA van die Westerse beskawing. Die media se invloed is goed bekend. Dit word egter gebalanseer met die ongelooflike groei van sosiale netwerke. Hiervoor is daar talle voorbeelde: van selfone tot Facebook en talle ander. Die wyse van sosialisering verander ook in die platteland. Nogtans is die nettoresultaat tans ' $n$ toename in diversiteit selfs in klein plattelandse gebiede. Ek moes dit telkens in meer detail aan die gemeentes verduidelik.

\section{Diversiteit}

Diversiteit het baie vorme. Ras, taal en kultuur is verantwoordelik vir die groot groeperinge. Diversiteit het egter veel kleiner skakerings. In die platteland is die volgende skerp op die voorgrond: spiritualiteit, ouderdom of generasies, geslagte, geloof, klas of opvoeding en vele meer. Die NGK-gemeentes betrek grotendeels Afrikaanse Blanke gelowiges. Binne die groep is daar baie diversiteit maar in die platteland word diegene wat Afrikaans is saamgebind en word daar hard probeer om tussen hulle eenheid te verkry. Hierdie groep het die meeste ekonomiese en intellektuele mag. Die NGK-lidmate het die politieke mag in 1994 verloor. Die getalsterkste groep in die gemeentskappe wat besoek is, is hoofsaaklik arm Kleurlingmense. Swart mense speel nie enige rol in die gemeentes wat besoek is nie, behalwe in die polisie. ' $n$ Klein plattelandse gemeente het ' $n$ groter verantwoordelikheid as net teenoor sy eie lidmate. Om as gemeenskap vrede te hê en te kan saamwerk en saamleef vra onvermydelik dat daar mense moet wees wat oor grense kan beweeg en kan saamwerk. Die NGK het tradisioneel nie sy rol in hierdie opsig goed verstaan nie. Apartheid het nie net teen die wese van die Skrif ingedruis nie, dit het ook mense en gemeenskappe van mekaar vervreem, iets wat die platteland besonder destruktief getref het. Om in ' $\mathrm{n}$ dienskneggestalte in hierdie opsig leiding te neem is een van die heel grootste uitdagings van klein plattelandse NGK gemeentes.

\section{Belhar}

Die Belhar Belydenis is die Vrye Gereformeerde Kerke in Suid-Afrika (VGKSA) se belydenisskrif waarin die kerk onomwonde die Bybel se standpunt oor rassisme uitgespel het. Ondanks die feit dat omtrent alle Gereformeerde kerke wêreldwyd die belydenis aanvaar het, skep dit sonder uitsondering spanning in die NGK se plattelandse gemeentes. Ek het in elke gemeente hieroor vrae gevra. Teenstrydighede is aan die orde van die dag. Die inhoud van die belydenisskrif verwoord die Bybelse standpunt wat ook die Blanke mense beskerm teen die omgekeerde rassisme wat tans so sterk in Suid-Afrika aanwesig is. Nogtans is die emosionele bagasie wat saam met die belydenis gaan soos ' $n$ sneller wat in hierdie gemeentes net verset oproep.

Geen Suid-Afrikaanse gemeenskap kan rassisme in sy geledere ontken nie, ook nie die gemeentes en gemeenskappe wat ek besoek het nie. Nogtans sou dit baie eensydig wees om net dit te sê. Die prentjie het ' $n$ ander kant. Ek wil dit verduidelik na aanleiding van wat ek waargeneem het. Stedelike gemeentes wat Belhar se aanvaarding voorstaan, doen dit gewoonlik uit die gemaklike posisie van vêr verwyderd leef van 'die ander' in gerieflike en netjiese voorstedelike woonbuurte. In die platteland is daar geen mens wat nie elke dag ten nouste saamwerk met Kleurlingemense nie. Trouens, hulle bly naby mekaar, al hoe meer ook langs mekaar in die klein dorpies. Amper al tien die gemeentes wat ek besoek het, het goeie verhoudings met die VGKSA. In baie van die gemeentes 
vind kanselruiling gereeld plaas en bedien VGK leraars die sakrament in NGK gemeentes as daar nie 'n NGK predikant is nie. My indruk is dat al hoe sterker verhoudings tussen die kerke in die Afrikaanssprekende gemeenskap gebou word. Hulle besef algaande beter in watter mate hulle mekaar nodig het. Om van bo af Belhar op hierdie gemeenskappe af te druk gaan kontra-produktief wees. Meer van Belhar se beginsels word waarskynlik in hierdie gemeenskappe prakties waar gemaak as in stedelike gemeentes.

\section{Angus Buchan}

Ek het in elke gemeente gevra wat die invloed van die KwaZulu-Natal evangelis, Angus Buchan, se optrede in die gemeenskap was. Sonder uitsondering was NGKlidmate by van sy byeenkomste. In twee van die gemeentes het dit spanning veroorsaak, deels omdat die gemeentes probleme met hulle eie predikante gehad het. Agt uit die tien gemeentes kon lidmate wat die byeenkomste bygewoon het goed akkommodeer en positief getuig oor verdieping wat lidmate ondergaan het. Spanning in die verband is nou verwant aan spiritualiteitverskille asook die spanning tussen die ouer meer tradisionele lidmate en die jonger geslag wat transformasie in eredienste en aanbidding voorstaan. Die twee groepe het mekaar nodig om ' $n$ balans te vind. Elke gemeente het ' $n$ sogenaamde 'kamp'-groep. Dit is hierdie lidmate wat voorkom dat 'n gemeente vasgevang raak in ' $n$ instandhoudingsbediening omdat hulle maklik oor grense beweeg en oop is vir nuwe insigte. Gemeentes wat sulke lidmate verloor, verstok maklik en verloor heel eerste die jonger geslag. Matteus 28:16-20 se opdrag het nie verval nie en om dit te ignoreer is om geestelik jou doodsvonnis te teken. Ek oordeel dat dit uiters noodsaaklik is om hieraan aandag te gee.

\section{Patriargie}

'n Saak wat diep versluier in meeste plattelandse gemeentes voorkom, het te make met die unieke situasie van die boerdery en erfplase. Daar is baie gevalle waar daar groot ongelukkigheid is tussen pa's en seuns. Hier is dit ' $n$ geval van die pa wat nie die plaas oorgee na hy 'aftree' nie en die seun wat telkens soos 'n slaaf bly werk en aan 'n lyntjie gehou word. Naas dit is daar die situasie dat die seun wat die plaas erf dikwels broers en susters in gelyke dele moet uitbetaal wat hom in 'n situasie plaas dat hy eintlik nooit finansieel op sy voete kan kom nie. So 'n vererwing beteken dat die kind wat boer eintlik tot finansiële ondergang of swaarkry verdoem word. Die verskil tussen boerdery voor 1994 en boerdery na 1994 is aansienlik. Hier is diep seer. Dit sal baie help as dit in die oopte gebring en aangespreek kan word.

'n Tweede gestalte van patriargie is waar vroue wat van elders kom en met plaaslike mans getrou het, ervaar dat hulle hul hele lewe in kommer bly. Hulle moet sorg dat die plaas 'n erfgenaam kry en verder moet hulle aan die tradisionele rol van die onderdanige vrou beantwoord (wat feitlik net 'n huis- en plaaswerker is). Dit lei tot huwelikspanning, egskeiding en baie hartseer.

\section{'n Rouproses}

'n Aspek van die plattelandse bediening wat mens help om die ouer mense te verstaan is om in te sien dat hulle verlies ervaar en terug hunker na wat onthou word as 'die goeie ou dae'. Hulle onthou die tyd toe kerke gebou is en toe die Afrikaner uit sy armoede opgestaan het. Dit was dae van harde werk en saamwerk. Vir hulle is die nuwe bedeling in Suid-Afrika sonder waardes en sekuriteit. Hulle ervaar dat alles nou op losse skroewe staan en hulle verstaan nie die jonger geslag en die onherroeplike veranderinge wat wêreldwyd ingetree het nie. Dié realiteit moet met groot empatie hanteer word.

\section{Teoretiese insette}

Teoretiese insette het baie gehelp om groter duidelikheid te bring oor wat om ons en met ons aan die gebeur is. Die volgende onderwerpe is spontaan gebruik na aanleiding van die gesprekke:

- Die wêreld gaan deur die grootste en mees ingrypende aanpassingfase ooit. In die laaste 50 jaar het meer veranderinge plaasgevind as alle veranderinge saamgevat voor dit. Dit het ' $n$ direkte verband met die situasie in die plattelandse gemeente. In die verband kan Thomas Friedman (2007) se The world is flat help om insig te bring.

- Die Westerse kerk is sterwend en verloor lidmate. In die suidelike (armer) lande groei die kerk egter fenomenaal. Die hartland van die Christelike kerk verskuif uit die weste na nuwe tuistes. Waarom gebeur dit en hoe raak dit die NGK? Die verskuiwings kan verduidelik word na aanleiding van verskeie boeke in die verband (kyk Tickle 2008) en illustrasies uit byvoorbeeld die Lausanne III byeenkoms in Oktober 2010 in Kaapstad.

- Ons is aan die einde van die Christendom periode wat in 400 n.C. ' $n$ aanvang geneem het. Dit is gebaseer op die skeiding tussen die kerk en die staat - so asof elkeen sy eie terrein het om te bestuur en hom uit die ander een se sake moet hou. Die kerke van die Westerse lande het gevolglik diep teologiese foutlyne. Soos met ' $n$ skaapras se teling is daar teologiese foute in ons ingeteel. Dié punt is met groot belangstelling bespreek. Die missionale kerkbeweging se literatuur is hier van toepassing en 'nuwe' Christene wat die Bybel vars lees help ons om te sien (Walls 2002).

- Aan die hand van die sosioloog Manuel Castells se boek The Power of Identity (2004) het ek verduidelik hoe die informasietegnologie en globalisering die wêreld verander. Twee veranderings staan uit: eerstens, MAG kry al hoe meer 'n nuwe inhoud. Mag was oor millenia fisiese mag - die mag van die sterkste, die mag van wapens. Dit is aan die verander. Inligting en kennis word al hoe meer ' $n$ sterker mag as fisiese krag en wapens (Castells 2004:421, 424-425). Tweedens: mense en groepe se identiteit word nou anders gevorm. Identiteit, sê hy, word op drie wyses gevorm. Tradisioneel het dit van bo na onder plaasgevind - legitimizing identity formation (ibid:8). Die sterkere het sy mag gebruik om sy ideologie te vestig. Hierdie top-down manipulasie kan geillustreer word met hoe in die apartheidsperiode 
Blanke Afrikaners bymekaar gehou (gemaak) is. Teen sodanige dominasie en manipulasie het resistance identity formation (Castells 2004:8) wêreldwyd ontstaan. Oral oor die wêreld is daar opstande teen regerings, diktature en verskillende vorms van oorheersing - die nuutste is in Egipte, Tunisië, Libië en die Arabiese wêreld, te sien. Islam fundamentalisme is ' $n$ vorm van legitimizing identity formation waar fundamentalistiese godsdiens ' $n$ baie groot rol speel (Castells 2004:12-23). Daar is opstand teen die manipulerende mag van mans oor vroue en kinders. Derdens is daar project identity formation (Castells 2004:8, 422-423). ' $n$ Voorbeeld van laasgenoemde is die ekologiese beweging en die missionale kerkontwikkeling (Castells 2004:168-191, 423). Communitas en die SuidAfrikaanse Vennootskap vir Gestuurde Gemeentes (SAVGG) se leiding en materiaal is in die verband genoem hoe hierdie verskuiwings onder leiding van die Woord en Gees verwerk kan word. ${ }^{6}$ Kerke wat van bo veranderinge probeer forseer met behulp van dogmatiese uitsprake val in die legitimizing identity formation kategorie en verloor nou angswekkend vinnig veld. Die koninkryk van God is God se projek en plaas die kerk op 'n project identity formation pad waar dissipelskap en die navolging van Christus in die krag van die Gees nuwe hermeneutiese prosesse ontsluit.

\section{Die finale konferensie}

Veertig mense uit agt van die tien gemeentes het die finale konferensie in Oktober in Calvinia bygewoon. Die hele Communitas-span was daar. Terugskouend is die navorser se indruk van dié konferensie een van vreugde, hoop en geloofsversterking. Die grootste deel van die oggend was gewy aan 'Wandel in die Woord' uit Esegiël 47, die examengebedsoefening ${ }^{7}$ en gesprekke aan die tafels in groepe van vier waar 'Karoo-stories' oor wat God aan die doen is, vertel en met die groter groep gedeel is. Dit was eenvoudig aangrypend om te hoor wat oral aan die gebeur is. Daar was 'n vraag-en-antwoord geleentheid waar indringende vrae wat intussen opgeduik het of oor gewonder is, gevra en bespreek is.

Die finale evaluerende gesprek was ingelei met die volgende vraag: 'Hoe kan julle die lewende water wees en hoe kan 'n fokus op God in julle gemeentes plaasvind?' En aanvullend: 'Wat wil julle van die PGO/Communitasspan vra vir die pad vorentoe?'

Die gemeentes het aan tafels gesit en die volgende antwoorde is gegee. Om die gees van die geleentheid weer te gee, word dit onveranderd uit die notule aangehaal ${ }^{8}$ :

1. Terug na God: Kerklike leierskap is geestelike leiers wie se taak is om mense na God te lei en by God te help uitkom. Kyk na julle kerkraadsnotules en kyk wat oorheers daar. Maak aanpassings soos nodig dat God en sy agenda weer die kerk se agenda word.

6.Kyk Communitas (s.a.).

7.Vir meer oor die gebedsoefening, kyk Ignatian Spirituality.com (n.d).

8.Kyk Hendriks (2011b:9).
2. Ontdek God se droom: Geestelike leiers moet van God 'n visie kry. Kyk na Esegiël 47 dit is 'n droom! Hierdie besef groei al hoe sterker in die NGK.

3. Geloofsonderskeidende leierskap: Bogenoemde gebeur waar daar geloofsonderskeidende leierskap is. Hier moet mens leer om die beheer terug te gee aan God ... wandel in die woord en luister na stories oor wat in die gemeentes gebeur. Hier is die belang van LUISTER so belangrik ... ons default heeltyd na praat en raadgee. Die ding wat in ons Kerkraadsvergadering moet gebeur is om God self aan die Woord te stel - dit kan jy net doen as dit as't ware 'n oop Bybel vergadering is en daar altyd ' $n$ tipe gebedshouding is om oop te wees vir foute wat jy gemaak het, en om dinge op te vang wat God alreeds aan die doen is. Skielik kom daar visie ... iets wat jy nie self 'kraam' nie, maar wat jy eintlik net helder besef omdat Christus se Gees jou oë daarvoor oopmaak.

4. Afhanklike gebed: Gebed is nie net voorbidding nie (nie inkopielys gebed nie). Gebed is om stil te word en te luister. Vergelyk die tabernakel gebedseminaar van Anita en Gert Hattingh; die gebedstasies van die tabernakel items is simbole wat ons almal baie gaan help.

5. Geestelike toerusting vir geestelike opbou vir roeping wat ontdek word: Lidmate het al hoe meer 'n behoefte aan dominees of geestelike leiers wat hulle kan help om self te ontdek wat God op hulle harte lê.

6. Vrouediens: Dis nie meer die koekies en tee ding nie. Vroue maak egter ' $n$ al groter verskil in die kerk. LW dit gaan nie om die instandhouding van programme en agendas nie, maar wat ook al God op vroue se agenda plaas.

7. Skep ruimtes om na mekaar te luister en mekaar te ondersteun. Luister na mekaar. Hê respek vir almal, selfs die wat van jou verskil. Daar is ' $n$ diep besef dat ons mekaar nodig het: as gemeentes in die Karoo, as mense in 'n groot gemeenskap. Gemeentes wat hulle isoleer en net met hulleself besig is raak die moerasse wat genoem word in Esegiël 47.

8. Tegnologie: Storie van Calvinia - gesteelde telefoonlyne lei daartoe dat hulle maste opgesit het en nou kry al hoe meer mense internet en selfoonontvangs. Skielik kan die kerk baie meer gereeld en baie makliker by mense uitkom. Bogenoemde is in terme van Esegiël 47 die water wat uit die tempel vloei en momentum optel.

Dit is duidelik dat hierdie gemeentes alles behalwe neerslagtig is en dat daar ' $n$ nuwe en positiewe gees te bespeur is. Daar is hoop en ' $n$ fokus op God. Die missionale hermeneutiek is duidelik.

\section{Finale gevolgtrekkings}

In hierdie beskrywende studie is die resultate van drie besoeke aan 'n aantal Karoo-gemeentes beskryf. Die kontekstuele en teologiese problematiek waarmee daar in die gemeentes geworstel word, is gesistematiseer en aangetoon. Die skrywer het basies na die gemeentes geluister en daarna bepaalde insette gemaak wat die gemeentes gehelp het. Die eerste oorsigtelike resultate van die hulp was duidelik by die finale konferensie. Ten slotte word die beskrywende verslag afgesluit met drie voorstelle wat 'n samevatting is van die konklusie waartoe gekom is. 


\section{'n Nuwe hermeneutiese sleutel tot die bediening: Missionale teologie}

Teologies is daar in terme van die toekoms van klein plattelandse gemeentes een pad om te volg en dit is om die wil van die Here te soek. As Hy die huis nie bou nie, bou ons tevergeefs. Ons sal moet begin om die wyse waarop kerkrade besluite neem aanpas om ' $n$ meer geloofonderskeidende kultuur te vestig wat daarop ingestel is om met die Woord te wandel en die wil en agenda van God te soek. Die debatstyl waarop die kerklike agenda gewoonlik ingestel is om ' $n$ instandhoudingsbediening te ondersteun, lei tot die geestelike dood van ' $n$ gemeente. In die verband is by die gemeentes aanbeveel om te kyk na Frederick Marais (2007) se boek God praat - leef luisterryk vir vergaderings. Gemeentes is verwys na verskeie MTh tesisse wat die omswaai van die instandhoudingskultuur in plattelandse gemeentes beskryf. ${ }^{9}$

\section{Verander die beroepstelsel}

Uit die verslag is dit duidelik hoe ' $n$ wesenlike rol die leraar in die plattelandse gemeente speel en hoe leraars en gemeentes feitlik ten gronde gaan as konflik in 'n gemeente - om watter rede ook al - sy tol begin eis. Elkeen van die gemeentes wat besoek was, sal dus pleit vir 'n hersiening van die huidige beroepstelsel. Ek kan nie sterk genoeg woorde hiervoor vind nie. Ek dink dit is onverantwoordelik en 'n onreg dat leraars en gemeentes in onverkwiklike situasies vasgevang raak en mense geestelike en sielkundige letsels opdoen net omdat die kerkverband nie die saak kan aanspreek en leraars in oorleg met gemeentes kan verplaas nie.

Die volgende vraag is telkens gevra: hoe sou u voorstel moet die plasing van leraars en hulle salarispakkette gereël word? By meer as een geleentheid is voorgestel dat die kerk met ' $n$ algemene salarisfonds sal werk. Alle gemeentes dra dan volgens ' $n$ bepaalde formule by en alle leraars ontvang hulle salarisse volgens 'n vasgestelde skaal daaruit. As sekere gemeentes hulle leraars meer as die skaal wil gee, doen hulle dit bo en buite die stelsel. Dit voorkom die ongesonde tendens dat leraars nie plattelandse gemeentes toe gaan nie, omdat hulle daar onderbetaal word en ook omdat daardie gemeentes soveel kleiner is. Klein gemeentes se lidmate gee per persoon in elk geval die hoogste dankoffer.

Die volgende kan bydra tot die begin van 'n gesprek en 'n voorstel:

- Elke sinode het 'n Beroep- en Plasingkommissie wat elke vyf jaar alle leraars se standplase nagaan met die verstek opdrag dat hy of sy skuif tensy goeie redes aangevoer word waarom nie. Tussen-sinodale skakeling vra 'n bepaalde persentasie oor-grens-skuiwe. Alle partye word geken in die proses.

- In elke sinode, gesinkroniseer in Algemeen Sinodale verband, word die salarisse en toelaes en/of kontrakte van alle leraars deur ' $n$ objektiewe paneel van deskundiges onderhandel. Alle partye (leraars en kerkrade) kan vertoë lewer, maar die finale aanbeveling berus by die kommissie.

9.Leon Venter (2010); Hannes Peens (2011) en Louis Smith (2011).

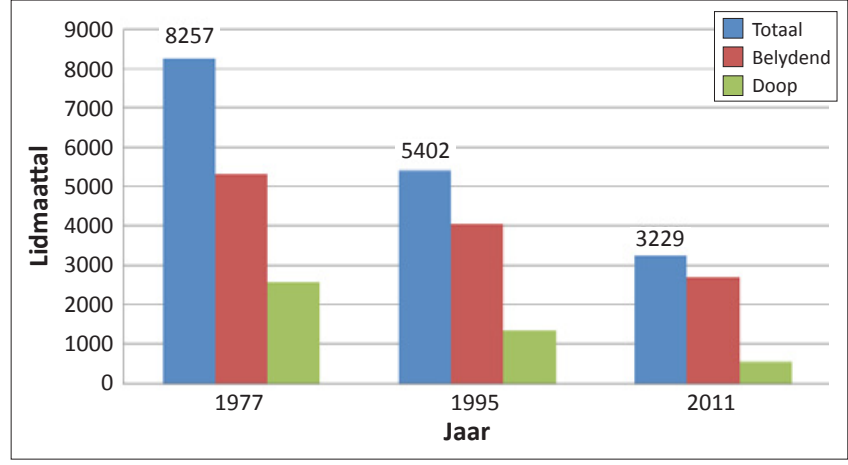

FIGUUR 1: Lidmaattal tendense van tien klein plattelandse gemeentes.

Die doel hiermee is eenvoudig: 'n sterker fasiliteringsrol by die vasstel van pakkette.

Bogenoemde skuiwe sal heelwat tyd neem om in te faseer. Dit is myns insiens dringend dat op sinodale vlak ' $n$ kommissie aangestel sal word om die vasstel van salarisse en toelaes op gemeentevlaktefasiliteer. Diehuidigeonderhandelingsproses tussen ' $n$ kerkraad se diensverhoudinge kommissie en 'n leraar of brugleraar skep te veel ongesonde spanning. Te veel mense word te na gekom. Leraars, brugleraars of selfs leraars wat op kontrak werk, is te uitgelewer aan die huidige situasie.

\section{Brugpredikante}

Die aanstel van 'n brugpredikant in gemeentes waar daar konflik was, is die regte ding om te doen. Gemeentes het hiervoor leiding nodig en die kerk behoort in sinodale verband asook oorkoepelend tussen streeksinodes hieraan aandag te gee. In drie van die tien gemeentes het brugpredikante uitstekende werk gedoen en is daar in 2012 oorgegaan tot beroeping.

\section{Erkenning Mededingende belange}

Die outeur verklaar dat hy geen finansiële of persoonlike verbintenis het met enige party wat hom nadelig kon beïnvloed in die skryf van hierdie artikel.

\section{Literatuurverwysings}

Babbie, E. \& Mouton, J., 2010, The practice of social research, Oxford University Press, Cape Town.

Castells, M., 2004, The power of identity: The information age: Economy, society and culture, vol. 2, 2nd edn., Blackwell, Oxford.

Communitas, s.a., 'SAVGG: Venootskap vir Gestuurde Gemeentes, Nuwe Clusters 10 2009', besigtig 02 April 2012, by http://www.communitas.co.za/vennootskapsavgg?lang

De Vos, A.S., Strydom, H., Fouche, C.B. \& Delport, C.S.L., [1998] 2011, Research at grass roots for social sciences and human service professions, 4th edn., Van Schaik, Cape Town

Dudley, C.S. \& Ammerman, N.T., 2002, Congregations in transition: A guide for analyzing, assessing, and adapting in changing communities, Jossey-Bass, San Fransisco

Friedman, T., 2007, The world is flat: A brief history of the twenty-first century, Picador, New York.

Guder, D.L. (ed.), 1998, Missional Church: A vision for the sending of the church in North America, Eerdmans, Grand Rapids.

Hendriks, H.J., 2004, Studying congregations in Africa, Lux-Verbi-BM, Wellington. 
Hendriks, H.J. 2011a, 'Plattelandse Gemeente Ondersteuningsinisiatief', verslag van besoeke aan agte gemeentes, ongepubliseerd.

Hendriks, H.J. 2011b, 'Plattelandse Gemeente Ondersteuningsinisiatief 2', verslag van opvolgbesoeke, ongepubliseerd.

Ignatian Spirituality.com, n.d., 'The Daily Examen', viewed 02 April 2012, from http:// www.ignatianspirituality.com/ignatian-prayer/the-examen/

Jung, L.S. \& Agria, M.A., 1997, Rural Congregational Studies, Abingdon, Nashville.

Kleingemeentes, 2012, 'Initiatief om plattelandse gemeentes te ondersteun', besigtig 02 April 2012, by http://kleingemeentes.co.za/

Marais, F., 2007, God praat - leef luisterryk vir vergaderings: Handleiding vir gemeenteleiers op soek na God se agenda vir gemeentes, Bybelkor, Wellington.

Nederduits Gereformeerde Kerk (NGK), 1977, 'Jaarboek van die Nederduitse Gereformeerde Kerke' Jaargang 128, Tydskriftemaatskappy, Braamfontein.

Nederduits Gereformeerde Kerk (NGK), 1995, 'Jaarboek van die Nederduitse Gereformeerde Kerke', Jaargang 146, Tydskriftemaatskappy, Goodwood.

Nederduits Gereformeerde Kerk (NGK), 2011, 'Jaarboek van die Nederduitse Gereformeerde Kerke' Uitgawe 162, Tydskriftemaatskappy, Wellington.

Niemandt, N., 2007, Nuwe drome vir nuwe werklikhede, Lux Verbi, Wellington.

Peens, H., 2011, 'Implikasies van 'n missionale transformasieproses vir die NG Gemeente Marken se voortbestaan', MTh tesis, Departement Praktiese Teologie en Missiologie, Universiteit van Stellenbosch. http://scholar.sun.ac.za/ handle/10019.1/6629
Sheridan, T.M., 2012, 'Being a hermeneutic of the gospel: Hermeneutical \& epistemological foundations for a missional ecclesiology', DTh dissertation Department Praktiese Teologie en Missiologie, Stellenbosch University. http:// scholar.sun.ac.za/handle/10019.1/19913

Smith, L., 2011, 'Kerkbegrip en Rolverwagtinge in die NG Gemeente Murray (De Doorns)', MTh tesis, Departement Praktiese Teologie en Missiologie, Universiteit van Stellenbosch. http://scholar.sun.ac.za/handle/10019.1/6741.

Tickle, P., 2008, The great emergence: How Christianity is changing and why, Baker, Grand Rapids.

Venter, L., 2010, 'Dans met Triniteit', MTh tesis, Departement Praktiese Teologie en Missiologie, Universiteit van Stellenbosch. http://scholar.sun.ac.za/ handle/10019.1/5355

Walls, A.F., 2002, The cross-cultural process in Christian History, Orbis, Maryknoll.

\section{Addendum}

\section{Lidmaatgetalle}

Die 2011 lidmaat getalle kom uit die gemeentes self. Die 1995 en 1977 NGK Jaarboeke is gebruik om die getalle vir die bepaalde groep gemeentes uit te kompileer. 